ORIGINAL ARTICLE

AFRICAN JOURNAL OF CLINICAL AND EXPERIMENTAL MICROBIOLOGY

AJCEM/21314

COPYRIGHT 2013

MAY 2013 ISBN 1595-689X VOL 14(2) 2013

-http://www.ajol.info/journals/ajcem

AFR. J. CLN. EXPER. MICROBIOL 14(2): 84-87 http:/ / dx.doi.org/10.4314/ajcem.v14i2.6

\title{
TRANSFUSION TRANSMISSIBLE VIRAL INFECTIONS AMONG POTENTIAL BLOOD DONORS IN IBADAN, NIGERIA.
}

\author{
Afolabi, A.Y. ${ }^{* 1}$, Abraham, A. ${ }^{2}$, Oladipo, E.K. ${ }^{1}$,Adefolarin, A.O. ${ }^{3}$ and Fagbami, A.H. ${ }^{1}$
}

${ }^{1}$ Department of Medical Microbiology and Parasitology, College of Health Sciences, LadokeAkintola University of Technology, Ogbomoso, Nigeria..2Department of Haematology, Blood Bank Unit, University College Hospital, Ibadan,

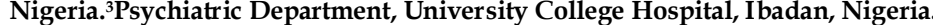

*Correspondence: e-mail: yettykay@yahoo.com

\begin{abstract}
It is evident that proper screening procedures prior blood transfusion is a cost-effective approach for prevention and control of transfusion-transmissible infections (TTIs). Also, it has been documented that sub-standard test kits are mostly used in resource limited settings for transfusion related diagnosis. However, the role of such practice in epidemiology of transfusion transmissible viral infections in a tertiary health care facility would give an insight to the rates of blood transfusion associated viral transmission in the community at large. Therefore, the study was designed to determine the prevalence of Human Immunodeficiency Virus (HIV), Hepatitis B and Hepatitis C viruses among blood donors in a tertiary hospital where quality diagnostic procedures are considered prior recruitment of donors. Post ethical approval, counselled and consenting 507(M= 426; $\mathrm{F}=81$ ) aged 19 to 68 years (Median age:39) potential blood donors were recruited and tested for HIV, HBsAg and anti-HCV using commercial ELISA testkit in strict compliance with the manufacturer'sprocedures. Overall results show rates of $2.0 \%, 5.9 \%$ and $\mathbf{1 . 4} \%$ for $\mathrm{HIV}, \mathrm{HBsAg}$ and $\mathrm{HCV}$ respectively. Also, highest prevalence rates were recorded among age group 26 to 35 years as $2.6 \%, 7.2 \%$ and $2.1 \%$ for $\mathrm{HIV}, \mathrm{HBV}$ and $\mathrm{HCV}$ respectively. Furthermore, higher prevalences rates were noted among unmarried individuals as $2.6 \%, 6.8 \%$ and $2.1 \%$ for $\mathrm{HIV}$, HBV and HCV respectively.
\end{abstract}

Key words: Transf usion Transmissible Infections, HIV, Hepatitis B, Hepatitis C, Blood Donors, University College Hospital (UCH), ELISA.

\section{INTRODUCTION}

The most common diseases transmitted in blood transfusions are viral infections. Transfusiontransmissible infectious agents such as human immunodeficiency virus (HIV), hepatitis B virus (HBV) and hepatitis $\mathrm{C}$ virus (HCV) are among the greatest threats to blood safety for the recipient. The discovery of transfusion-transmissible infections (TTIs) has heralded a new era in blood transfusion practice worldwide with emphasis on two fundamental objectives, safety and protection of human life [1]. Human immunodeficiency virus (HIV), hepatitis B virus (HBV) and hepatitis C virus $(\mathrm{HCV})$ are of great concern as transfusiontransmissible infections because of their prolonged viraemia and carrier or latent state. They also cause fatal, acute, chronic and life-threatening disorders. Blood transfusion accounts for $5-10 \%$ of HIV infections in sub-Saharan Africa [2]. Similarly, $12.5 \%$ of patients who received blood transfusion are at risk of post-transfusion hepatitis [3]. Therefore, this study was carried out to determine the seroprevalence, among selected group and trends of HIV, HBV and HCV among donors at University College Teaching Hospital in Ibadan Nigeria.

\section{MATERIALS AND METHODS \\ Study Centre}

The Study centre was located in Ibadan, Oyo State, situated in the tropical belt of Southern Western part of Nigeria. The study is at the Blood Bank of University College Hospital, Ibadan, Nigeria.

Study Population

The study participants were potential blood donors presenting at the blood bank of the University College Hospital, Ibadan between February and July 2010. Total of Five hundred and seven samples was collected from the prospective donors.

Sample Collection (Blood)

Samples were collected in a tube without anticoagulant. A tourniquet was firmly tied to the upper arm of the donor while sitting and skin sterilizer with $70 \%$ alcohol. The sterile needle was inserted into conspicuous antecubital vein and the plunger of the sterile syringe was withdrawn and pressure applied to the puncture site with a cotton wool to stop bleeding. Blood sample was spun on a bench centrifuge at $3,000 \mathrm{rpm}$ for 10 minutes to obtain serum. Serum or plasma was separated immediately.

Data Collection and Laboratory Methods

A survey of the blood sample of the prospective donors at the Blood Bank, University College Hospital (UCH) Ibadan was conducted between February - July 2010 using structured questionnaire. Descriptive statistics and correlation analysis was performed to check the relationship between the data and laboratory test results observed and inference was drawn using an inferential statistics (SPSS version 15). 
A cross-sectional study was conducted from February to July, 2010 at blood bank of the University College Hospital, (UCH) Ibadan. The total samples included all the donors, presented and consented to participate during the study period. Prior to blood collection, the blood donors were required to answer questionnaire. After consent was obtained and pre-test counselling was done, and the questionnaire was completed. $5 \mathrm{mls}$ of blood sample was collected in sterile tubes without anticoagulant from each study participant using a vacutainer needle. Serological examination was conducted on each sample.

Serum samples were tested as follows: for HIV 1 and HIV 2 using BIO-RAD GenscreenELISA made in France; for HBsAg using BIO- RAD monolisa ultramade in France; for HCV-AbDIA.PRO ELISA made in Italy was used.

\section{RESULTS}

Table 1 shows prevalence of $\mathrm{HbsAg}$, HIV and HCV antibody in the study population. Out of 507 participants whose sera were tested using ELISA, 30 (5.9\%) were positive for $\mathrm{HbsAg}, 7(1.4 \%)$ for $\mathrm{HCV}$ and $10(2.0 \%)$ for HIV.The highest prevalence of HBsAg (7.2\%) was found in persons whose ages were between 26-35 years as shown in Table 4 . The prevalence of $\mathrm{Hbs} \mathrm{Ag}$ in theother age groups was as follows; $16-25$ years $(6.6 \%)$, 36-45 years $(4.2 \%), 46-55$ years $(4.7 \%)$.

The prevalence of HbsAg in age group 26-35 years was significantly higher than the other age groups. The difference observed in the prevalence of HbsAg among different age group, was not statistically significant $\mathrm{P}>0.05$.

\section{TABLE 1: PREVALENCE OF HEPATITIS B SURFACE ANTIGEN (HBSAG), HEPATITIS C (HCV) AND HUMAN IMMUNODEFICIENCY VIRUS (HIV) AMONG THE STUDY PARTICIPANTS.}

\begin{tabular}{|l|l|l|l|}
\hline Virus & Total NoTested & \multicolumn{2}{|l|}{ Seropositive } \\
& & $\%$ & No \\
\hline HbsAg & 507 & 5.9 & 30 \\
\hline HCV & 507 & 1.4 & 7 \\
\hline HIV & 507 & 2.0 & 10 \\
\hline
\end{tabular}

\section{TABLE 2:PREVALENCE OF HEPATITIS B SURFACE ANTIGEN (HBSAG), HEPATITIS C (HCV) AND HUMAN IMMUNODEFICIENCY VIRUS (HIV) ANTIBODIES AMONG DIFFERENT}

AGE GROUPOF STUDY PARTICIPANT

\begin{tabular}{|l|l|l|l|l|l|}
\hline \multirow{2}{*}{} & \multicolumn{4}{|l|}{ AGE IN YEARS } & \\
\cline { 2 - 6 } & $\begin{array}{l}16-25 \\
\text { No }(\%)\end{array}$ & $\begin{array}{l}26-35 \\
\text { No }(\%)\end{array}$ & $\begin{array}{l}36-45 \\
\text { No }(\%)\end{array}$ & $\begin{array}{l}46-55 \\
\text { No }(\%)\end{array}$ & $\begin{array}{l}\text { TOTAL } \\
\text { No }(\%)\end{array}$ \\
\hline HBsAg & $9(6.6)$ & $14(7.2)$ & $5(4.2)$ & $2(4.7)$ & $30(6.0)$ \\
\hline HCV Positive & $2(1.5)$ & $4(2.1)$ & $1(0.8)$ & $0(.0)$ & $7(1.4)$ \\
\hline HIV Positive & $2(1.5)$ & $5(2.6)$ & $2(1.7)$ & $1(2.3)$ & $10(2.0)$ \\
\hline
\end{tabular}

\section{TABLE 3:PREVALENCE OF HEPATITIS B SURFACE ANTIGEN (HBSAG), HEPATITIS C (HCV) AND HUMAN IMMUNODEFICIENCY VIRUS (HIV) ANTIBODIES AMONG THE MARRIED AND UNMARRIED PARTICIPANTS}

\begin{tabular}{|l|l|l|l|l|}
\hline Marital Status & No Tested & $\begin{array}{l}\text { HbsAg } \\
\text { No (\%) Positive }\end{array}$ & $\begin{array}{l}\text { HCV } \\
\text { No (\%) Positive }\end{array}$ & $\begin{array}{l}\text { HIV } \\
\text { No (\%) Positive }\end{array}$ \\
\hline Married & 297 & $17(5.7)$ & $3(1.0)$ & $4(1.3)$ \\
\hline Unmarried & 192 & $13(6.8)$ & $4(2.1)$ & $5(2.6)$ \\
\hline Total & 489 & $30(6.1)$ & $7(1.4)$ & $9(1.8)$ \\
\hline
\end{tabular}

The results of tests for HCV antibody in the study population is shown in Table 1 . Out of the 507 sera tested for antibody to HCV $7(1.4 \%)$ were positive. The age distribution of HCV antibody test result in the study is shown in Table 4. The highest prevalence of $\mathrm{HCV}$ antibody $(2.1 \%)$ was found in 26-35 years age group. Prevalence of HCV antibody in the other age groups are as follows; $16-25$ years $(1.5 \%)$ and $36-45$ years $(0.8 \%)$.

Out of 507 study participants (individual blood donors) whose sera were tested for HIV antibody 10 $(2 \%)$ were positive. The age distribution of HIV antibody in this study is shown in Table 2. The highest prevalence of HIV antibody (2.6\%) was found in 26-35 years age group. Prevalence of HIV antibodies in the other age groups was as follows; $16-25$ years $(1.5 \%), 36-45(1.7 \%)$ and $46-55$ years $(2.3 \%)$. There was no significant difference between prevalence of HIV antibody among the different age groups, $\mathrm{P}>0.05$.

A total of 489 study participants with different marital status were tested for $\mathrm{Hbs} \mathrm{Ag}$ and antibodies to $\mathrm{HCV}$ and HIV. The prevalence of $\mathrm{HbsAg}, \mathrm{HCV}$ and HIV antibody in married and unmarried participants is shown in Table 3. Out of 297 married study participants $17(5.7 \%)$ had HbsAg in their 
sera, $3(1.0 \%)$ and $4(1.3 \%)$ were positive of $\mathrm{HCV}$ and HIV antibodies respectively .Out of 192 unmarried, $13(6.8 \%)$ were positive for $\mathrm{HbsAg}, 4(2.1 \%)$ and $5(2.6 \%)$ were positive for HCV and HIV antibodies respectively. The prevalence of $\mathrm{HbsAg}$, and $\mathrm{HCV}$ antibody was higher among the unmarried participants than in married individuals, the difference is statistically significant $\mathrm{P}>0.05$. Prevalence of HIV antibody among the unmarried was higher than married. There was a statistical significance $(\mathrm{P}<0.05)$ difference between HIV prevalence among the unmarried and the married participants.

\section{DISCUSSION}

Blood transfusion is the process of transferring blood or blood-based products from one person into circulatory system of another, to save lives in some medical conditions. Although blood transfusion saves million of lives worldwide each year, recipients of the blood or blood product transfusions stand the risk of becoming infected with blood-borne diseases such as human immunodeficiency virus (HIV), hepatitis B virus (HBV) and hepatitis $\mathrm{C}$ virus (HCV), through transfusion of infected blood and blood products [4].The discovery that HIV, HBV and HCV could be transmitted by blood transfusion has provoked a greatly heightened emphasis on two fundamental objectives, safety and protection of human life [5]. Transfusion transmissible infections (TTIs) are a very serious complication of blood transfusion [6]. These infections continue to pose a great challenge to transfusion medicine, most especially in Africa, due to a high transfusion demand [7]. Hepatitis B and $C$ viruses and HIV are distinct, but share a similar mode of transmission, primarily; through unscreened and contaminated blood and blood products by contact or transfusion. Other routes include sexual intercourse and vertical transmission from mother to foetus in the immediate pre-natal period $[8,9]$.

Prevention of transfusion transmitted infections (TTIs) in developed countries has been achieved by reducing unnecessary blood transfusionand exclusion of donors with specific risk of viral infections.By contrast, in many developing countries, none of these interventions is applied uniformly and the risk of (TTIs) remains high. The high incidence and prevalence of (TTIs) in the blood donors in developing countries means that, some agents escape laboratory detection,[10].

In this study 507 donors were recruited into the study with ages ranging from age 16 years to 68 years. In general blood donors must fulfil certain requirements, one of which is the age requirement of between 18 - 60 years. This explains why no study subject was below age 19 and only a few were above 60 years old. There was a predominance of males among the study participants because females are not encouraged to donate blood in Nigeria society. Also, most of the replacement donors are men. Prevalence of HbsAg (6.8\%) and antibody to HCV (2.1\%) in this study was significantly higher among the unmarried participants than in married individuals. The prevalence of HIV antibody in unmarried was higher than the married. Higher prevalence values for HbsAg, HCV and HIV antibody in unmarried may be due to the fact that the unmarried individuals are more likely to engage in behaviours that put them at risk of all these infections than the married participants.

The findings of this study showed that hepatitis B and $\mathrm{C}$ viruses and HIV are circulating in Ibadan and infecting the residents of the city, including the blood donors. Hepatitis B surface antigen, HCV and HIV antibodies found were $5.9 \%, 1.4 \%$, and $2.0 \%$, respectively. The result of this study on the prevalence of $\mathrm{HbsAg}$ in blood donors in $\mathrm{UCH}$, Ibadan isdifferent from that ofOlaleye, et al.,[11], which showed a very high prevalence $(30.8 \%)$ of $\mathrm{HbsAg}$ in Ibadan. The prevalence HbsAg in blood donors in Ibadan is also lower than that found by Okerengwo and Mudasiru[12], when they tested sera of blood donors for $\mathrm{HbsAg}$ in the same location, this may be due to the awareness and effect of HIV control programmes in the society, for the fact that they share the same route of transmission.The seroprevalence of $\mathrm{HCV}$ antibody found among blood donors in this study is lower than that reported by previous workers. Fashola, et al.,[13] showed the prevalence of HCV antibody among blood donors in $\mathrm{UCH}$, Ibadan was $4.96 \%$. Studies carried out in other location in Nigeria also showed a higher prevalence of HCV antibody in blood donors than that found in the present study. Isa, et al.,[14] found HCV antibody prevalence of $1.8 \%$ among blood donors in Kaduna, Kaduna state, Nigeria. Studies carried out by Egah, et al., [15] in Jos, Plateau state, Nigeria showed that the prevalence of $\mathrm{HCV}$ antibody among blood donors was 6\%. Chukwurah, et al.,[16] and Ayolabi, et al.,[17] also found higher prevalence of HCV antibody among blood donors. A study carried out in South-Eastern state of Nigeria, Chukwurah, et al., [16] found that $7.6 \%$ of blood donors had HCV antibody in their sera. In similar study carried out in Lagos, Nigeria Ayolabi, et al.,[17] reported that $8.4 \%$ of blood donors were positive for $\mathrm{HCV}$ antibody.

Marked variation in the prevalence of HIV antibody of HIV antibody has been reported in different part of Nigeria. Some workers have reported prevalence of HIV to be lower than the $2 \%$ found in this study, while others reported higher prevalence of HIV antibody from some locations [18, 19,13]. Ejele, et al., [18] found that $4 \%$ of blood donors in Port Harcourt, South-Southern Nigeria had HIV antibody.

Overall, the prevalence of $\mathrm{HbsAg}$, HCV and HIV antibodies found in this study is one of the lowest 
ever reported from Nigeria. This observation may probably be due to the positive impact of HIV education and public enlightenment campaign which have been in place in Ibadan and everywhere for many years and which helped in reducing the spread of HIV in Nigeria. Since HIV, HCV and HBV have similar modes of transmission, the reduction in prevalence of HIV infection in the community will also lead to a reduction in $\mathrm{HBV}$ and $\mathrm{HCV}$ transmission. Another factor that may account for the low prevalence of HbsAg, HCV and HIV antibody is donor recruitment. Infections by these three viruses are more common in commercial and replacement donors than voluntary donors. It is possible that most of the donors whose sera were tested in this study were voluntary donors.

Age distribution of $\mathrm{HbsAg}, \mathrm{HCV}$ and $\mathrm{HIV}$ revealed that there was no significant difference in the prevalences of $\mathrm{HbsAg}, \mathrm{HCV}$ and HIV

\section{REFERENCES}

[1]. Klein H.G. Allogenic transfusion risk in the surgical patients. AMJ surg,1995;170:21-26.

[2]. UNAIDS.Report on the global AIDS epidemic. Geneva, Joint United Nations program on HIV/ AIDS 2002.

[3]. Fasola F.A. andOtegbayo I.A. Posttransfusion hepatitis in sickle cell anaemia;retrospective-prospective analysis. Nig J ClinPract2002; 5:16-19.

[4]. UNAIDS Women and AIDS.UNAIDS point of view UNAIDS. Geneva 2007.

[5]. Tapko J.B., Sam O. and Diarra-Nama A.J. Status of blood safety in the WHO African region report of the 2004survey.WHO 2007.

[6]. World Health Organization. Blood Safety Strategy for the African Region. Brazzaville, World Health Organization, Regional Office for Africa (2002).(WHO AFR / RC51/9 Rev.1).

[7]. Fleming A.F. HIV and Blood Transfusion in sub-Saharan Africa.

Transfusion science.1997;18:167-179

[8]. Busch M.P., Young M.J., Samson S.M., Mosley J.W., Ward J.W. and Perkins H.A. Risk ofHuman immunodeficiency virus (HIV) transmission by blood transfusions before the implementation of HIV-1 antibody screening. The transfusion safety study group. Transfusion1991;31(1):4-11.

[9]. Federal Ministry of Health, Nigeria. Sentinel survey among pregnant women. 2008.

[10].Campbell J, Hagan H, Latka M, Garfein R, Golub E, Coady M, Thomas D, and Strathdee S antibody among the different age groups of blood donors. Youths aged 21-30 constituted the highest number of HIV and hepatitis B infection, HBV had 21, $\{1.4 \%\}$ seropsitivity; HIV had15 $\{1.0 \%\}$ seropisitivity and age $31-40$ had $1(0.1 \%)$ for $\mathrm{HCV}$.

Results of the study which showed that the prevalence of $\mathrm{HbsAg}$, HCV and HIV antibody is $5.9 \%, 1.4 \%$ and $2.0 \%$ suggest that these three major transfusion transmissible viral infections are still causing considerable morbidity in the communities and continue to pose a major challenge for blood safety. It seems that the prevalence of these viral infections is lower than that was reported by previous workers. This suggests that the disease control measures of the Federal government of Nigeria and Nongovernmental organizations (NGO) are making a positive impact in the spread of these viral infections.

"High prevalence of alcohol use among hepatitis $C$ virus antibody positive injection drug users in three US cities.". Drug Alcohol Depend2006;81 (3): 259-65.

[11].Olaleye O.D.,EkweozorC.C. and Meyer C. Hepatitis B surface antigen in patients attending the sexually transmitted disease clinic in Ibadan. Afri J. Med. Sci1996;25:117-121

[12].Okerengwo A. A. and Mudashiru A. A. Immune complex levels and HBs antigenemia in healthy Nigerians and patients with liver diseases. African Journal of Medicine and medical sciences1992; Vol 21: 35-38

[13].Fasola F.,Kotila T. and AkinyemiJ.O.Trends in Transfusion transmitted viral infections from 2001-2006 in Ibadan Nigeria. Intervirology2008 ;51:427-431.

[14].Isa A.H., Hassan A. and Mamman A. I. Seroprevalenceof hepatitis C virus antibodies among blood donors in Ahmadu Bello University Teaching Hospital, Kaduna. Afr. J. Cln. Exper.

Microbiol.2009; 11: 75-78.

[15].Egah, D.Z., Mandong B.M., Iya D., Gomwalk N.E., Audu E.S. , BanwatE.B. andOnile B.A., Hepatitis C Virus Antibodies among Blood Donors in Jos, Nigeria.Annals of AfricanMedicine,2004;3(1): 35-37.

[16].Chukwurah E.F., Ogbodo S.O., Obi G.O.

Seroprevalence of Hepatitis C Virus (HCV) among blood donors in South Eastern States of Nigeria. Biomedical research 2005;16: 133-135.

[17].Ayolabi, C.I., Taiwo M.A., Omilabu S.A., Abebisi A.O., Fatoba O.M. Sero-prevalence 
of Hepatitis C Virus among Blood Donors in Lagos, Nigeria. Nigeria. African J. Biotechnol.,2006;5(20): 1944-1946

[18].Ejele O.A., Nwauche C.A. and Erhabor O. Seroprevalence of HIV infection among

Blood donors in port Harcourt, Nigeria. Nigerian Journal of Medicine.;2005;14:287-289.
[19].Imoru M., Eke C.andAdegoke A.Prevalence of Hepatitis-B Surface Antigen (HbsAg), Hepatitis C Virus (HCV) and Human Immunodeficiency Virus (HIV) among Blood Donors in Kano State, Nigeria. Medical Laboratory Sci.,2003;12(1): 59-63. 